\title{
LEACHING OF RARE EARTH ELEMENTS WITH SULFURIC ACID FROM BASTNASITE ORES
}

\author{
Srećko R. Stopića ${ }^{a}$ Bernd G. Friedrich ${ }^{b}$ \\ RWTH Aachen University, IME Process Metallurgy and Metal \\ Recycling, Aachen, Federal Republic of Germany \\ a e-mail: sstopic@ime-aachen.de, \\ ORCID iD: (Dhttp://orcid.org/0000-0002-1752-5378 \\ b e-mail: bfriedrich@ime-aachen.de, \\ ORCID iD: (1)http://orcid.org/0000-0002-2934-2034
}

DOI: 10.5937/vojtehg66-17177; https://doi.org/10.5937/vojtehg66-17177

\author{
FIELD: Chemical Technology \\ ARTICLE TYPE: Original Scientific Article \\ ARTICLE LANGUAGE: English
}

\section{Summary:}

Dissolution of rare earth elements from bastnasite ores was studied using sulfuric acid at the atmospheric pressure. The one step strategy with sulfuric acid was studied further and the results showed that filtering difficulties do not happen for the chosen parameter combinations. Furthermore, the best parameter combinations were those with low temperatures and low acid concentrations. All in all, direct leaching is a simple process that uses the cheapest acid on the market and offers good leaching recoveries. Attention should be given to the formation of gel, especially when taking the process to the large scale, and the subsequent elimination of $\mathrm{Ca}$ from the leachate.

Key words: rare earth elements, hydrometallurgy, bastnasite, sulfuric acid.

\section{Introduction}

Rare earth elements are a group of metallic elements of the periodic table, often overlooked, but very significant in today's industrial landscape and modern lifestyle. Like other metals, rare earths are silvery-gray, malleable, ductile, and conduct electricity.

ACKNOWLEDGMENTS: The research leading to these results has received funding from the European Community's Seventh Framework Programme (Call identifier FP7-NMP2012-LARGE-6) under grant agreement $n^{\circ} 309373$. This publication reflects only the author's view, exempting the Community from any liability. Project website: www.eurare.eu. We would like to thank FEN Minerals, Norway, for sending their Rodberg sample and for their discussion in our experimental work. 
They appear in nature in the form of oxides and other compounds, but with one particularity - the chemical similarity between all of them is so astounding that they all occur together in their bearing minerals, substituting one another at the molecular level (Gupta\& Krishnamurthy, 2005), (Castor et al, 2006, pp.769-792).

Europe has never been known for having rich and substantial rare earth deposits; they do, however, exist in the continent's northern area, especially in the Scandinavian countries. As lower grade ores and different mineral formations are coming into the focus of industrial interest, many research projects have been set up. The European Commission has been willing to participate in these efforts through the EURARE project, aimed at setting "the basis for the development of a European Rare Earth Element industry" and to "safeguard the interrupted supply of rare earth raw materials and products crucial to sectors of the EU economy". (Chen, 2011, pp.1-6)

Bastnasite $\left((\mathrm{La}, \mathrm{Ce}) \mathrm{CO}_{3} \mathrm{~F}\right.$ is a fluororcarbonate of the cerium group found in ore deposits, metamorphic zones and pegmatites. In average, it contains $70 \%$ rare earth oxides (most of them belonging to the light fraction), particularly lanthanum, cerium and neodymium (Rare Earth Elements, British Geological Survey). The amount of thorium present in the mineral is negligible. This mineral is the primary source of rare earth oxides in Bayan Obo, China and Mountain Pass, California, the two most world-relevant rare earth mining complexes (Hoshino et al, 2016, pp.129291). At the Mountain Pass Mine in California and the Bayan Ono mine in China, bastnasite concentrate containing between $60-70 \%$ REO is commercially processed via a calcination $/ \mathrm{HCl}$ leach route to recover the rare earth elements.

The sulfuric acid leaching process was studied for processing roasted ore of Dechang bastnasite in Sichuan, China, in order to obtain rare earth elements (Feng et al, 2013, pp.849-854). Using particle size $(0.074-0.100 \mathrm{~mm}), 1.5 \mathrm{~mol} / \mathrm{L}$ sulfuric acid concentration, mass ratio of liquid to solid 8 and stirring speed of $500 \mathrm{rpm}$, the reaction rate of the leaching process can be controlled by diffusion through the product/ash layer, as described by the shrinking-core model, and the calculated activation energy of 9.97, which is typical for a diffusion controlled process.

Geological surveys carried out in Norway have revealed the existence of a rare earth deposit south west of Oslo, and one of its ores, named Rodberg, is thought to be an especially promising source of rare earth elements. The chemical nature and the grain size of Rodberg's bastnasite minerals are however quite different from those of other ores 
being currently exploited, which is why Rodberg requires a custom-made process for rare earth recovery. Traditional rare earth ore processing methods are due to Rodberg's mineralogical characteristics not easily applicable and have been discarded. The reason for this is the low grain size of Rodberg's rare earth bearing minerals within the rock formation (Balomenos et al, 2017, pp.142-153). The grain size of rare earth bearing minerals determines whether it is easy or not to obtain a rare earth concentrate through physical separation from other minerals of low value. The first step in separating the minerals is known as mineral liberation: ores are ground in order for rare earth minerals to become detached from the rest of the ore material. The rare earth minerals such as eudialyte and steenstripine can be then separated from the ore and the result is a rare earth physical concentrate. Working with a concentrate in further processing steps increases the efficiency of leaching and chemical treatment, and is the way extraction methods have been traditionally designed. Two alternative processing possibilities have been proposed for the treatment of bastnasite ore, both of them related to the high presence of iron oxides in the ore.

1) The first of these processing possibilities consists of conducting direct leaching. Since Rodberg is formed by a matrix of iron oxides in which the rare earth elements - carbonates - are embedded, acids are expected to attack the rare earth minerals more readily than the more stable iron oxide matrix. This means that it would be possible to reduce acid consumption as well as the excess dissolution of unwanted species in the leaching operation without the need of a concentrate.

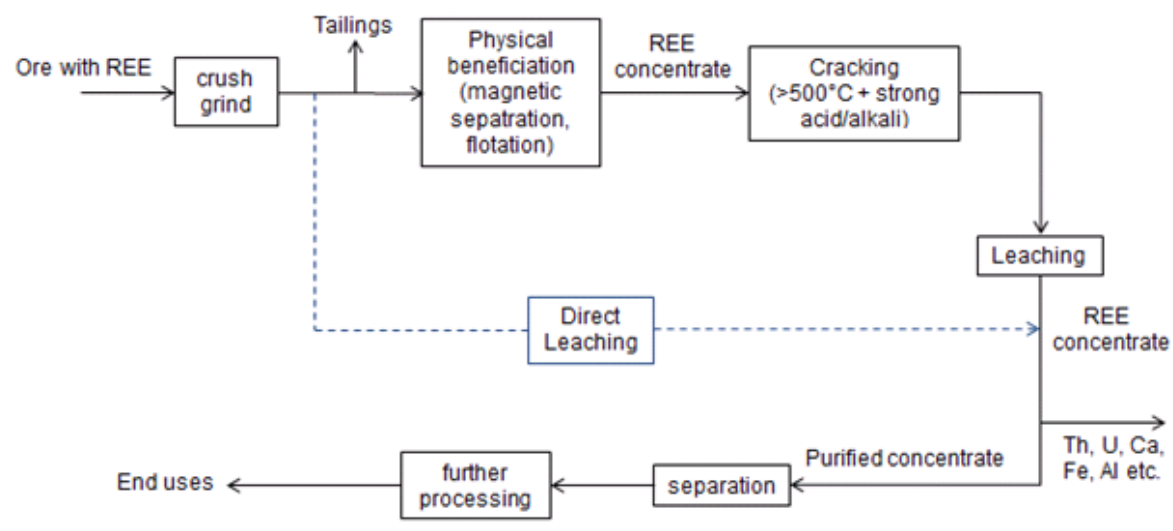

Figure 1 - Traditional and Direct leaching route for processing of bastnasite Рис. 1 - Традиционный и прямой метод обработки фрторкарбонатов Слика 1 - Традиционални и директни метод обраде фрлуорокарбонатног минерала 

as:

The main equations ruling dissolution in sulfuric acid are described

$$
\begin{aligned}
& 2 \mathrm{REFCO}_{3}+3 \mathrm{H}_{2} \mathrm{SO}_{4} \rightarrow \mathrm{RE}_{2}\left(\mathrm{SO}_{4}\right)_{3}+2 \mathrm{HF}+2 \mathrm{H}_{2} \mathrm{CO}_{3} \\
& \mathrm{CaCO}_{3}+\mathrm{H}_{2} \mathrm{SO}_{4} \rightarrow \mathrm{CaSO}_{4}+\mathrm{H}_{2} \mathrm{CO}_{3} \\
& \mathrm{Fe}_{2} \mathrm{O}_{3}+3 \mathrm{H}_{2} \mathrm{SO}_{4} \rightarrow \mathrm{Fe}_{2}\left(\mathrm{SO}_{4}\right)_{3}+3 \mathrm{H}_{2} \mathrm{O} \\
& \mathrm{MnO}+\mathrm{H}_{2} \mathrm{SO}_{4} \rightarrow \mathrm{MnSO}_{4}+\mathrm{H}_{2} \mathrm{O}
\end{aligned}
$$

2) The second processing route is related to the carbothermic reductive smelting of the bastnaesite ore for steel manufacture, producing metallic iron and a slag.Once smelted, the slag should contain a high fraction of rare earth elements together with other compounds that normally appear in slags. Therefore, the slag can be considered a rare earth concentrate suitable for leaching operations in acid and for subsequent recovery of REEs.

\section{Experimental work}

\section{Material}

The experiments were performed using the bastnasite ore with a higher content of iron in the form of iron-oxides $(73,1 \%)$, as shown in Table 1.

Table 1 - Composition of the sample of the bastnasite ore

Таблица 1 - Состав образцов руды с содержанием фоторкарбонатов

Табела 1 - Састав узорка руде која садржи фрлуорокарбонатни минерал

\begin{tabular}{|l||l|l|l|l|l||l|l|l|l|l|l|l|l|}
\hline Element & $\begin{array}{l}\mathrm{Fe} \\
(\%)\end{array}$ & $\begin{array}{l}\mathrm{Ca} \\
(\%)\end{array}$ & $\begin{array}{l}\mathrm{Mg} \\
(\%)\end{array}$ & $\begin{array}{l}\mathrm{Mn} \\
(\%)\end{array}$ & $\begin{array}{l}\mathrm{Si} \\
(\%)\end{array}$ & $\begin{array}{l}\mathrm{La} \\
(\%)\end{array}$ & $\begin{array}{l}\mathrm{Ce} \\
(\%)\end{array}$ & $\begin{array}{l}\mathrm{Nd} \\
(\%)\end{array}$ & $\begin{array}{l}\mathrm{Pr} \\
(\mathrm{ppm})\end{array}$ & $\begin{array}{l}\mathrm{Sm} \\
(\mathrm{ppm})\end{array}$ & $\begin{array}{l}\mathrm{Gd} \\
(\mathrm{ppm})\end{array}$ & $\begin{array}{l}\mathrm{Tb} \\
(\mathrm{ppm})\end{array}$ & $\begin{array}{l}\mathrm{Y} \\
(\mathrm{ppm})\end{array}$ \\
\hline Amount & 73,1 & 6,75 & 0,5 & 0,45 & 1,39 & 0,16 & 0,61 & 0,45 & 831 & 512 & 93 & $<10$ & $<10$ \\
\hline
\end{tabular}

The total REE $(\mathrm{La}+\mathrm{Ce}+\mathrm{Pr}+\mathrm{Nd}+\mathrm{Sm}+\mathrm{Gd})$ content is $1.36 \%$. Although the content of thorium was about $1000 \mathrm{ppm}$, the behavior and precipitation of this metal during the sulfuric acid leaching will not be considered in this work.

\section{Experimental procedure}

The direct leaching process of bastnasite was performed using the hydrometallurgical equipment shown in Figure 2. 
The 2l-capacity reactor is based on a double-walled glass container, were the desired temperature for the experiment is programmed in device number 8 , and heated water is pumped between the reactor's walls to keep uniform temperature in the tank. A coiled condenser prevents vapor fumes from leaving the reactor, while a series of openings can be used to introduce a thermocouple and a $\mathrm{pH}$ meter. The reactor is also equipped with a broad stainless steel stirrer.

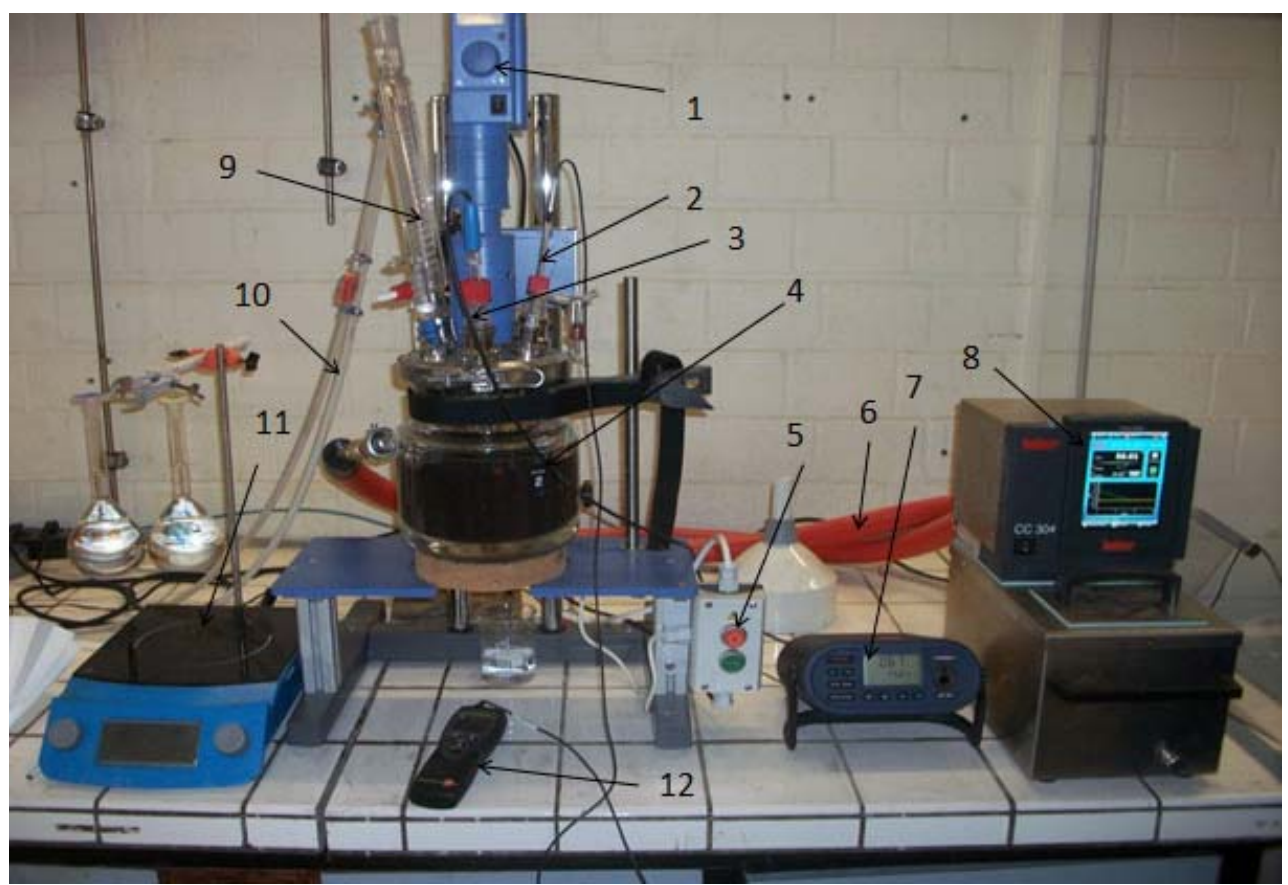

1. stirring speed control

2. thermocouple

3. $\mathrm{pH}$ meter

4. double-walled glass reactor

5. security stop
6. pipes for temperature regulation

7. $\mathrm{pH}$ reader

8. water pumping and heating
9. condensator

10. pipes for condensator

11. heating induction plate

12. temperature reader

Figure 2 - Hydrometallurgical equipment for direct leaching process

Puc. 2 - Гидрометаллургическое оборудование для прямого выщелачивания Слика 2 - Хидрометалуршка опрема за процес директног растварања

The experiments were carried out as outlined below. First, the diluted sulfuric acid solutions were prepared and poured into the reactor. When the experiment temperature was $65^{\circ} \mathrm{C}$ and higher, the acid was 
preheated in an induction plate to save time. The reactor was then covered, the condensation circuit turned on, and the pipes were connected to the temperature control device, already programmed at the desired temperature. The stirring speed was then selected, and the previously weighed bastnasite ore was poured with a funnel through one of the openings. The stopwatch was activated. The $\mathrm{pH}$ readings were noted during the duration of the experiment. Once the reaction time was over, the necessary devices were stopped and disconnected to allow opening the lid. The container's content was filtered using a vacuum filtering machine and the leachate was collected. Afterwards, the solid remains in the reactor container were washed out with distilled water onto the same filter paper and both were soaked with distilled water for neutralization. These filter papers were carried to a drying oven set at $105^{\circ} \mathrm{C}$ for $4 \mathrm{~h}$. The dried residue was weighed. Some samples precipitated white crystals a few hours after the leaching operation. Filtration was carried out and the precipitate was once again weighed.

\section{Experimental design}

The five chosen parameters for the leaching process were: sulfuric acid concentration, temperature, dissolution time, solid-liquid ratio and stirring speed. Each parameter was made to have 5 levels. For example, temperature can be varied between the levels $20,35,50,65$, and $80{ }^{\circ} \mathrm{C}$. Table 2 summarizes these parameters and their levels.

Table 2 - Factors and levels for the experimental design

Таблица 2 - Факторы и этапы планирования эксперимента

Табела 2 - Фактори и нивои планирања експеримента

\begin{tabular}{|l|l|l|l|l|l|}
\hline & level 1 & level 2 & level 3 & level 4 & level 5 \\
\hline acid concentration $(\mathrm{mol} / \mathrm{l})$ & 1 & 1,5 & 2 & 2,5 & 3 \\
\hline temperature $\left({ }^{\circ} \mathrm{C}\right)$ & 20 & 35 & 50 & 65 & 80 \\
\hline time $(\mathrm{min})$ & 20 & 50 & 80 & 110 & 140 \\
\hline solid-liquid ratio $(\mathrm{g} / \mathrm{l})$ & 50 & 100 & 150 & 200 & 250 \\
\hline stirring speed $(\mathrm{rpm})$ & 40 & 70 & 100 & 130 & 160 \\
\hline
\end{tabular}

Determining the levels of a variable requires an in-depth understanding of the process, including the limits within which it makes sense to range these values, and the likelihood that these values will contribute to an optimal performance characteristic. The number of levels chosen is an important matter, since more levels mean more accuracy but also an increase in the number of experiments to be conducted. Experimental design for the determination of an optimal parameter 
combination was used according to the Taguchi method (Khaw et al, 1995, pp.225-245). One of the advantages of the Taguchi method in relation to the traditional methods for experimental design (such as full factorial design) is that it allows for the analysis of a large number of parameters ranging along a large number of levels, with the minimum of experiments.

Table 3 - Experimental design

Таблица 3 - Планирование эксперимента

Табела 3 - Планирање експеримента

\begin{tabular}{|c|c|c|c|c|c|}
\hline experiment number & $\begin{array}{l}\text { conc. } \\
(\mathrm{mol} / \mathrm{l})\end{array}$ & temp. $\left({ }^{\circ} \mathrm{C}\right)$ & time $(\min )$ & $\begin{array}{c}\text { s-I ratio } \\
(\mathrm{g} / \mathrm{l})\end{array}$ & $\begin{array}{l}\text { str. Speed } \\
\text { (rpm) }\end{array}$ \\
\hline 1 & 1 & 20 & 20 & 50 & 40 \\
\hline 2 & 1 & 35 & 50 & 100 & 70 \\
\hline 3 & 1 & 50 & 80 & 150 & 100 \\
\hline 4 & 1 & 65 & 110 & 200 & 130 \\
\hline 5 & 1 & 80 & 140 & 250 & 160 \\
\hline 6 & 1,5 & 20 & 50 & 200 & 100 \\
\hline 7 & 1,5 & 35 & 80 & 250 & 130 \\
\hline 8 & 1,5 & 50 & 110 & 50 & 160 \\
\hline 9 & 1,5 & 65 & 140 & 100 & 40 \\
\hline 10 & 1,5 & 80 & 20 & 150 & 70 \\
\hline 11 & 2 & 20 & 80 & 100 & 160 \\
\hline 12 & 2 & 35 & 110 & 150 & 40 \\
\hline 13 & 2 & 50 & 140 & 200 & 70 \\
\hline 14 & 2 & 65 & 20 & 250 & 100 \\
\hline 15 & 2 & 80 & 50 & 50 & 130 \\
\hline 16 & 2,5 & 20 & 110 & 250 & 70 \\
\hline 17 & 2,5 & 35 & 140 & 50 & 100 \\
\hline 18 & 2,5 & 50 & 20 & 100 & 130 \\
\hline 19 & 2,5 & 65 & 50 & 150 & 160 \\
\hline 20 & 2,5 & 80 & 80 & 200 & 40 \\
\hline 21 & 3 & 20 & 140 & 150 & 130 \\
\hline 22 & 3 & 35 & 20 & 200 & 160 \\
\hline 23 & 3 & 50 & 50 & 250 & 40 \\
\hline 24 & 3 & 65 & 80 & 50 & 70 \\
\hline 25 & 3 & 80 & 110 & 100 & 100 \\
\hline
\end{tabular}




\section{Results and discussion}

The liquors collected where in a range of colors going from very clear yellow to dark brown. In a few cases, the solution was completely colorless.

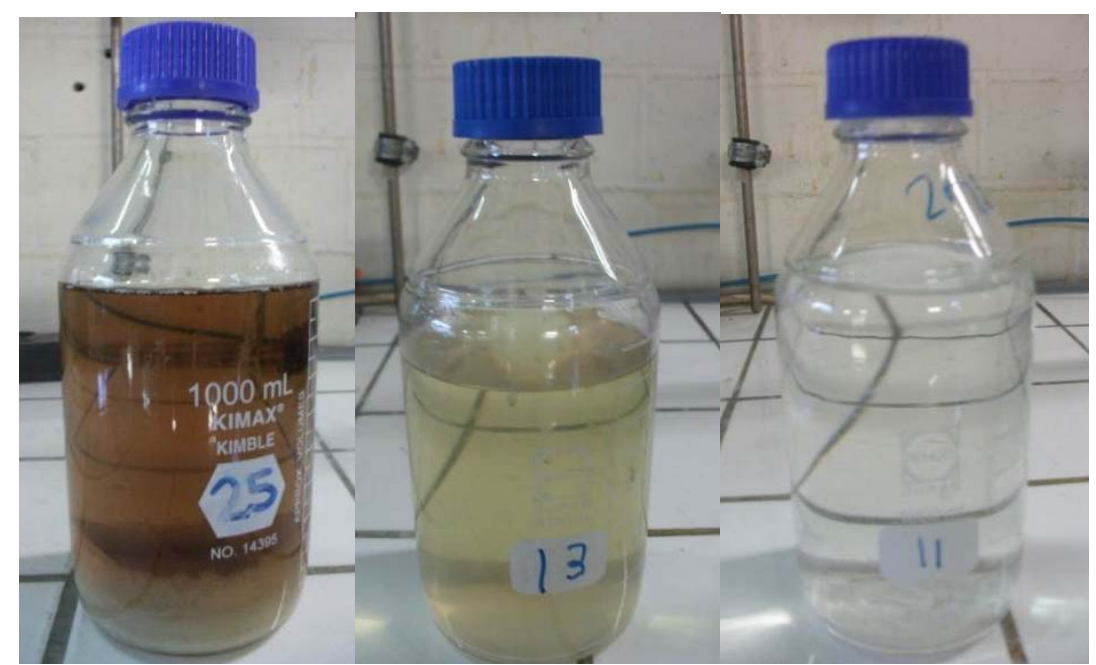

Figure 3 - The obtained solutions in experiments 11, 13 and 25 Puc. 3 - Полученные в ходе эксперимента растворы

Слика 3 - Добијени раствори у експериментима 11, 13 и 25

As expected, after two or three hours, a white precipitate appeared at the bottom of many liquor bottles. This precipitate kept on appearing for two or three days after leaching had been carried out. The texture of this precipitate varied significantly. Crystals were thick in some cases, while in other cases they were extremely small, forming gels. The existence of gels could be easily seen while filtering the precipitate because filtering became extremely difficult and even lasted an hour or two. The appearance of gel during filtering operations and the texture of other filtered precipitates is given in Figure 4.

The formation of gel is a serious problem, because filtering operations become unviable, and rare earth elements are lost. In the collected data, the amount of the formed gel was categorized as high, medium or low. High levels of gel meant that the filtering operation of 1 l liquor took between 1 and $2 \mathrm{~h}$. 


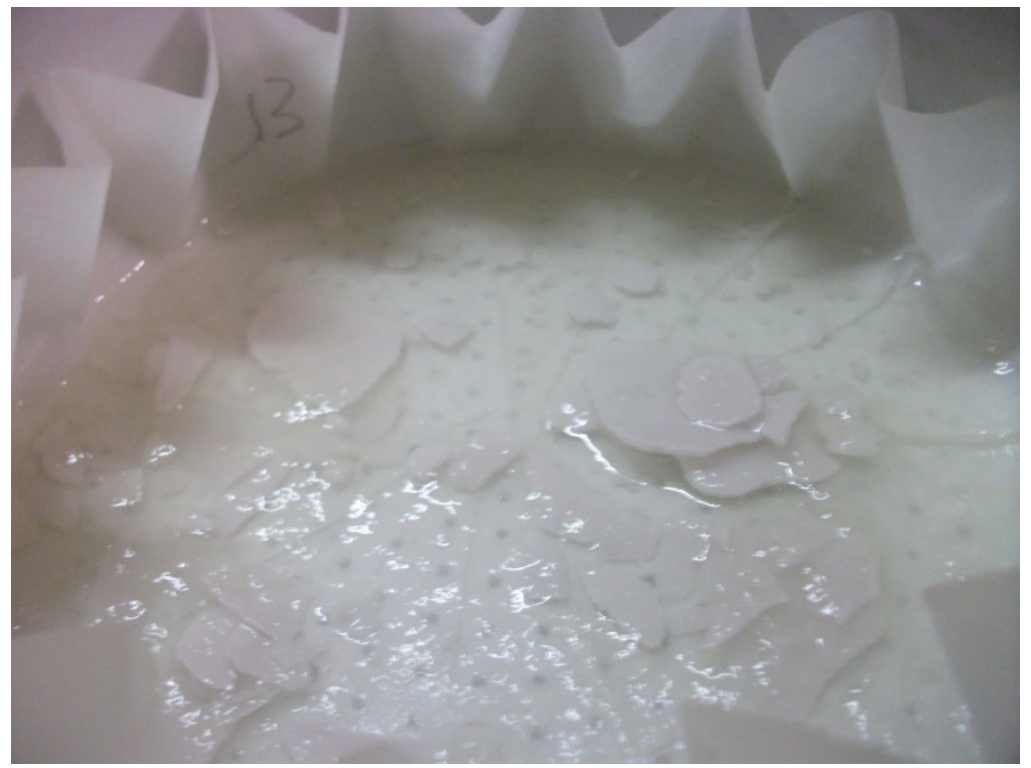

Figure 4-Typical gel formation in Experiment. 13

Puc. 4 - Типичное образование геля в эксперименте 13

Слика 4 - Карактеристично формирање гела у експерименту 13

The following observations can be made from the obtained results presented in the graphs in Figure 5 to describe the effects of the reaction parameters on the REE behavior during dissolution from the bastnasite ore.

- Sulfuric Acid concentration: Concentration only affects the recovery of REEs slightly. Middle and middle-low concentrations give the best results.

- Temperature: High temperatures hinder the dissolution of REEs. This is consistent with literature (the solubility of rare earth sulfates increases as temperatures decrease). Middle ranged temperatures are the best option.

- Time: Dissolution increases with time during the first hour of leaching and remains high for longer times.

- Solid to liquid ratio: Higher solid to liquid ratios are more favorable than low ones. This is not a common behavior for mineral dissolution.

- Stirring speed: A minimum of stirring is needed for dissolution to be effective. 

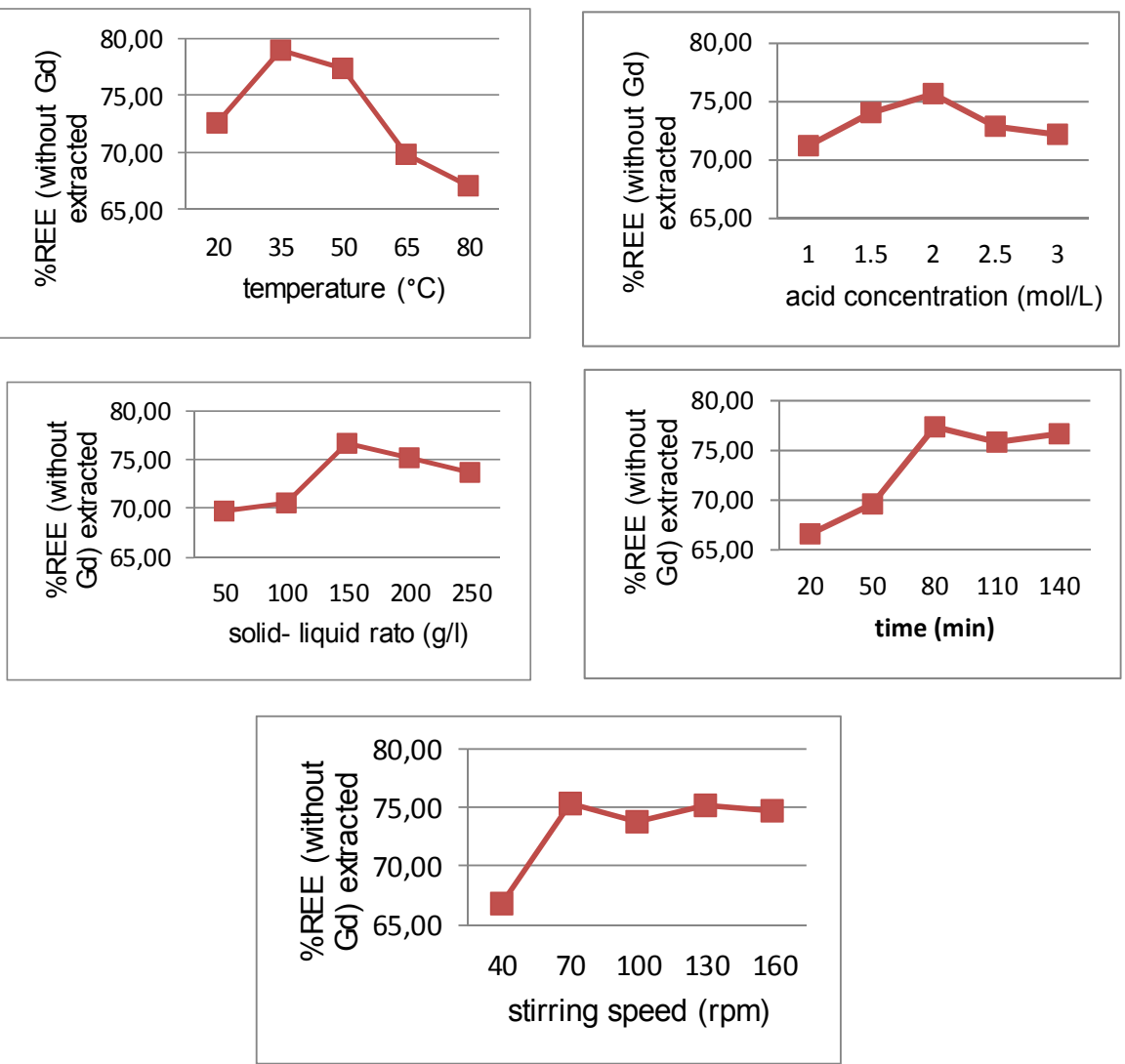

Figure 5 - Main effects graphs for rare earth extraction from bastnasite ore by direct leaching with sulfuric acid

Puс. 5 - Графики основных эфффектов экстракции редкоземельных элементов из фоторкарбоната, путем прямого выщелачивания, с помощью серной кислоты

Слика 5 - Приказ утицаја главних параметара екстракције ретких земаља

директним растварањем руда које садрже фрлуорокарбонатни минерал

The optimum of each factor is the level with a maximum mean; in other words, the highest value in the main effects graphs: $2 \mathrm{M}, 35^{\circ} \mathrm{C}$, $80 \mathrm{~min}, 150 \mathrm{~g} / \mathrm{l}$ and $70 \mathrm{rpm}$. No experiment has been done for this parameter combination. However, there is a very similar experiment, experiment number $12\left(2 \mathrm{M}, 35^{\circ} \mathrm{C}, 110 \mathrm{~min}, 150 \mathrm{~g} / \mathrm{l}\right.$ and $\left.70 \mathrm{rpm}\right)$, where the only difference is $20 \mathrm{~min}$ longer leaching time, with high gel formation. This means that there is danger that the optimal parameter combination would be affected by gel, and it is, therefore, not a suitable option. 
We can also conclude that the levels chosen for each factor were convenient, since the maximum dissolution of REEs happens in the middle values of levels.

From all the experiments, the one with the highest average of REEs dissolved is experiment number $3\left(1 \mathrm{M}, 50^{\circ} \mathrm{C}, 80 \mathrm{~min}, 150 \mathrm{~g} / \mathrm{l}\right.$ and $\left.100 \mathrm{rpm}\right)$. For this combination, all rare earth elements except $\mathrm{Nd}$ and $\mathrm{Sm}$ dissolve to their highest value $(96.7 \%$ of cerium, $95 \%$ for praseodymium, $79.58 \%$ for lanthanum). The average of REEs extracted is also at its highest point with $85.12 \%$. Neodymium is most difficult to extract: the maximum dissolution occurs for experiment $13\left(2 \mathrm{M}, 50^{\circ} \mathrm{C}, 140 \mathrm{~min}, 200 \mathrm{~g} / \mathrm{l}\right.$ and $\left.70 \mathrm{rpm}\right)$. Unfortunately, this experiment produces gel. The second best value for $\mathrm{Nd}$ is also experiment 3 that produces no gel. Other advantages of experiment number 3 are that it requires a minimum amount of acid, and that the dissolution of $\mathrm{Fe}$ is especially low with only $2.19 \%$.

A high amount of gel was formed in experiments 7, 12 13, 17 and 23. What these experiments have in common is that they were all carried out at temperatures of 35 and $50^{\circ} \mathrm{C}$. Concentration does not seem to be a decisive factor. There is gel for concentrations of $1.5,2$ and $3 \mathrm{M}$. None of the $1 \mathrm{M}$ experiments produced gel. The 2,5M experiments did not have gel either, although lower and higher concentrations did cause gel formation. However, the experiments with a concentration of 2,5M and in the range of temperatures mentioned were performed with lower solid per liquid ratios. Most other experiments with gel were performed with 200 to $250 \mathrm{~g} / \mathrm{l}$ of bastnasite ore. The formation of gel is connected to the dissolution of silicium and silica undergo hydrolysis. Unfortunately, experiments with gel are between those with higher rare earth recovery ratios. Experiments 7,12 and 13 give the three best dissolution values for REEs after experiment 3. Although this is not studied here, dry digestion process can be applied in order to prevent gel formation (Davris et al, 2017, pp.115-122), (Ma et al, 2018, p.267).

The leaching process of bastnasite ore is a very complicated process were many chemical components and mechanisms are taking place at the same time and are guided by different driving forces. Many dissolution studies have been carried out so far, in which the object was to understand the dissolution behavior of individual minerals or more simple mixtures with similar dissolution characteristics. The recovery of rare earths from Rodberg bastnasite ore with sulfuric acid is however surrounded by many phenomena, including the precipitation of calcium sulfate, calcite passivation, re-dissolution and reprecipitation of gypsum and anhydrate, adsorption of rare earths by calcium sulfate crystals and gel formation. These phenomena are influenced by factors such as concentration and temperature to different extents. The result is an extremely complicated system. 
Although the detailed analysis of means was in some cases not able to provide clear trends in the dissolution of bastnasite ore, it did help identify some of the main factors involved in the dissolution of components and the amount of formed precipitates or solid residues.

\section{Conclusion}

Sulfuric acid leaching of Rodberg bastnasite ore from Norway containing an average of $1.36 \%$ REEs was studied in the direct leaching process. The one step strategy with sulfuric acid was studied further and the results showed that filtering difficulties do not happen for all parameter combinations. The optimum of each factor is the level with a maximum mean; in other words, the highest value in the main effects graphs: $2 \mathrm{M}, 35^{\circ} \mathrm{C}, 80 \mathrm{~min}, 150 \mathrm{~g} / \mathrm{l}$ and $70 \mathrm{rpm}$.

Furthermore, the best parameter combinations were those with low temperatures and low acid concentrations. All in all, it is a simple process that uses the cheapest acid on the market and offers good leaching recoveries. Attention should be given to the formation of gel, especially when taking the process to the large scale, and the subsequent elimination of $\mathrm{Ca}$ from the leachate. If these issues are solved, sulfuric acid leaching represents the best option for processing the bastnaesite ore. In order to solve it, dry digestion process with sulfuric acid and subsequent leaching with water were proposed.

\section{References}

Balomenos, E., Davris, P., Deady, E., Yang, J., Panias, D., Friedrich, B., Binnemans, K., Seisenbaeva, G., Dittrich, C., Kalvig, P., \&Paspaliaris, I. 2017. The EURARE Project: Development of a Sustainable Exploitation Scheme for Europe's Rare Earth Ore Deposits. Johnson Matthey Technology Review, 61(2), pp.142-153. Available at: https://doi.org/10.1595/205651317x695172.

Castor, B., James, B., \& Hedrick, B. 2006. Rare Earth Elements. In J.E. Kogel, N.C. Trivedi, \& J.M. Barker Eds., Industrial Minerals and Rocks, pp.769-792.

Chen, Z. 2011. Global rare earth resources and scenarios of future rare earth industry. Journal of Rare Earths, 29(1), pp.1-6. Available at: https://doi.org/10.1016/s1002-0721(10)60401-2.

Davris, P., Stopic, S., Balomenos, E., Panias, D., Paspaliaris, I., \& Friedrich, B. 2017. Leaching of rare earth elements from eudialyte concentrate by suppressing silica gel formation. Minerals Engineering, 108, pp.115-122. Available at: https://doi.org/10.1016/j.mineng.2016.12.011.

Feng, X., Long, Z., Cui, D., Wang, L., Huang, X., \& Zhang, G. 2013. Kinetics of rare earth leaching from roasted ore of bastnaesite with sulfuric acid. Transactions of Nonferrous Metals Society of China, 23(3), pp.849-854. Available at: https://doi.org/10.1016/s1003-6326(13)62538-8. 
Gupta, C.K., \& Krishnamurthy, N. 2005. Extractive Metallurgy of Rare Earths. Boca Raton, FI: CRC Press. chapter 1. 2; ISBN 0415333407 9780415333405.

Hoshino, M., Sanematsu, K., \& Watanabe, Y. 2016. REE Mineralogy and Resources. In Handbook on the physics and chemistry of rare earths. Elsevier BV, pp.129-291. Available at: https://doi.org/10.1016/bs.hpcre.2016.03.006.

Khaw, J.F.C., Lim, B.S., \& Lim, L.E.N. 1995. Optimal design of neural networks using the Taguchi method. Neurocomputing, 7(3), pp.225-245. Available at: https://doi.org/10.1016/0925-2312(94)00013-i.

Ma, Y., Stopic, S., Gronen, L., Milivojevic, M., Obradovic, S., \& Friedrich, B. 2018. Neural Network Modeling for the Extraction of Rare Earth Elements from Eudialyte Concentrate by Dry Digestion and Leaching. Metals, 8(4), p.267. Available at: https://doi.org/10.3390/met8040267.

Rare Earth Elements, British Geological Survey, Natural environment research council, center for sustainable mineral development, 2011. November, downloaded on November 24th 2013 from: https://www.bgs.ac.uk/downloads/start.cfm?id=1638.

ВЫЩЕЛАЧИВАНИЕ РЕДКОЗЕМЕЛЬНЫХ ЭЛЕМЕНТОВ СЕРНОЙ КИСЛОТОЙ ИЗ ПОРОД, СОДЕРЖАЩИХ ФТОРКАРБОНАТЫ

Сречко Р. Стопич, Бернд Г. Фридрих

Технический университет города Ахен,

Институт металлургических процессов и рециклирования металлов,

Федеративная Республика Германия

ОБЛАСТЬ: химические технологии

ВИД СТАТЬИ: оригинальная научная статья

ЯЗЫК СТАТЬИ: английский

Резюме:

В данной работе представлены результаты исследований по растворению редкоземельных элементов из руд, содержащих фрторкарбонаты, с помощью серной кислоты, при атмосферном давлении. Результаты выщелачивания с помощью серной кислоты показали, что фильтрование в процессе выбора различных параметров не влечет за собой негативных последствий. Наилучшие показатели были при комбинировании параметров с наиболее низкими температурами и наименьшей концентрацией кислоты. Прямое выщелачивание представляет собой весьма простой процесс, в осуществлении которого используется самая дешевая кислота на рынке сбыта. Особое внимание следует уделять образованию геля, особенно если в течение процесса использовался большой объем раствора, а также на последующее удаление кальция из раствора.

Ключевые слова: редкоземельные элементы, гидрометаллургия, фоторкарбонаты, серная кислота. 

КИСЕЛИНОМ ИЗ РУДА КОЈЕ САДРЖЕ ФЛУОРОКАРБОНАТНИ МИНЕРАЛ

Срећко Р. Стопић, Бернд Г. Фридрих

Технички универзитет у Ахену, Институт за процесну металургију и рециклирање метала, Савезна Република Немачка

ОБЛАСТ: хемијске технологије

ВРСТАЧЛАНКА: оригинални научни чланак ЈЕЗИК ЧЛАНКА: енглескИ

Сажетак:

Испитивано је растварање елемената ретких земаља из руда које садрже фрлуорокарбонатни минерал помоћу сумпорне киселине при атмосфрерском притиску. Резултати растварања у једном кораку помоћу сумпорне киселине показују да не долази до проблема приликом филтрирања при избору разних параметара. Најбоље су се показале комбинације параметара с ниским температурама и малим концентрацијама киселине. Директно растварање је једноставан процес у којем се користи најјефтинија киселина на тржишту. Посебну пажњу треба обратити на фрормирање гела, нарочито током процеса с већим запреминама раствора, као и на накнадно уклањање калцијума из раствора.

Кључне речи: елементи ретких земаља, хидрометалургија, фолуорокарбонатни минерал, сумпорна киселина.

Paper received on / Дата получения работы / Датум пријема чланка: 15.04.2018. Manuscript corrections submitted on / Дата получения исправленной версии работы / Датум достављања исправки рукописа: 01.07.2018.

Paper accepted for publishing on / Дата окончательного согласования работы / Датум коначног прихватања чланка за објављивање: 03.07.2018.

(c) 2018 The Authors.Published by Vojnotehnički glasnik / Military Technical Courier (www.vtg.mod.gov.rs, втг.мо.упр.срб). This article is an open access article distributed under the terms and conditions of the Creative Commons Attribution license (http://creativecommons.org/licenses/by/3.0/rs/).

() 2018 Авторы. Опубликовано в «Военно-технический вестник / Vojnotehnički glasnik / Military Technical Courier» (www.vtg.mod.gov.rs, втг.мо.упр.срб). Данная статья в открытом доступе и распространяется в соответствии с лицензией «CreativeCommons» (http://creativecommons.org/licenses/by/3.0/rs/).

(c) 2018 Аутори. Објавио Војнотехнички гласник / Vojnotehnički glasnik / Military Technical Courier (www.vtg.mod.gov.rs, втг.мо.упр.срб). Ово је чланак отвореног приступа и дистрибуира се у складу са Creative Commons licencom (http://creativecommons.org/licenses/by/3.0/rs/).

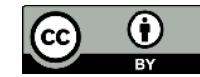

